\title{
Evidence for Natural Reproduction by Stocked Walleyes in the Saginaw River Tributary System, Michigan
}

\author{
DAVID J. JUDE \\ Center for Great Lakes and Aquatic Sciences \\ University of Michigan, Ann Arbor. Michigan 48109. USA
}

\begin{abstract}
A program of stocking walleyes Stizostedion vitreum into Saginaw Bay, Lake Huron. begun in the late 1970s by the Michigan Department of Natural Resources and sportsmen's groups. resulted in large spawning runs in tributary streams in the early 1980 s as water quality in the bay improved. Natural reproduction was documented by a 2-year sampling effor for larval walleyes that revealed the presence of substantial numbers of larvae over a 15-18-d period, with maximum densities (350-3,500/1,000 $\mathrm{m}^{3}$ ) recorded on 21 April 1987 and 6 May 1988 in the Saginaw River and on 6 May 1988 on the Tittabawassec River. More larval walleyes were collected at night and near bottom $(3 \mathrm{~m})$ than during the day and near the surface $(1 \mathrm{~m})$. The Tittabawassee River, one of four major rivers that form the Saginaw, was a major source of walleye larvae collected in the Saginaw River, but some walleye larvae were also collected in the Shiawassee River. Over 500,000 walleye larvae passed by the study area on the Saginaw River in $24 \mathrm{~h}$ on 21 April 1987. Using discharge and average walieye density data, I calculated that approximately 3 million walleye larvae passed by the study area during the 20-d period of occurrence in 1987 and approximately 28 million during a comparable period in 1988. I was able to confirm entry of some walleye larvae into Saginaw Bay with four tows at the river mouth during peak densities at the upriver study site. Adult walleye stocks are now abundant enough to produce substantial numbers of offspring, but environmental factors (flow reversals, poor water quality) or biological factors (predation, starvation) may be preventing successful recruitment to the Saginaw Bay sport fishery.
\end{abstract}

Saginaw Bay of Lake Huron has been one of the most productive areas for fish in the upper Great Lakes (Baldwin and Saalfeld 1962). Prior to the 1940 s the bay supported self-sustaining stocks of lake trout Salvelinus namaycush, walleye Stizostedion vitreum, lake whitefish Coregonus clupeaformis, and lake herring $C$. artedi (Leach et al. 1977; Schneider and Leach 1977). Dams, eutrophication, and-more recently-toxic substances have been linked to the demise of naturally reproducing populations of lake trout and walleye and have severely reduced other stocks. Since the late 1970s, water quality has improved in the bay (IJC 1980; Bierman and Dolan 1986a, 1986b); in response, a rehabilitation effort to reestablish walleyes was undertaken in the late 1970s and early 1980s and continues today (Mrozinski et al. 1991). The Michigan Department of Natural Resources, in cooperation with local sportsmen's groups, has stocked several local ponds annually to rear walleyes before restocking them at sizes of $40-65 \mathrm{~mm}$ into Saginaw Bay in mid-June. These efforts have resulted in spawning runs of up to 250,000 adults (Mrozinski et al. 1991) into accessible tributaries of Saginaw Bay each spring. Some adults may also be using historical offshore spawning reefs in Saginaw Bay (Schneider 1977). Whether spawning by these stocked fish contributes to the recruitment of walleyes to the bay, or whether naturally produced fry affect the stocked walleye fingerlings, forage fish, or yellow perch Perca flavescens of the Saginaw Bay ecosystem is unknown. This lack of knowledge is confounding efforts to efficiently manage the Saginaw Bay commercial and sport fisheries.

Estuaries and bays in populated areas have always been important to society. Most have been degraded by development, overfishing, wetlands destruction, and industrial and domestic waste disposal. Rehabilitation of these ecosystems starts with improved water quality. To rehabilitate valuable fisheries, innovative research is needed to determine broken links in life cycles. With this knowledge. the likelihood of making appropriate and effective management decisions is increased. Saginaw Bay represents an opportunity to substantially improve our knowledge of walleyes and other important fish stocks, and to develop information that should be applicable to other ecosystems whose fisheries require extensive rehabilitation.

The research presented herein addresses the hypothesis that stocked walleyes spawn successfully in Saginaw Bay tributaries and that naturally produced walleyes eventually drift into Saginaw Bay. Objectives of the study were (1) to document 


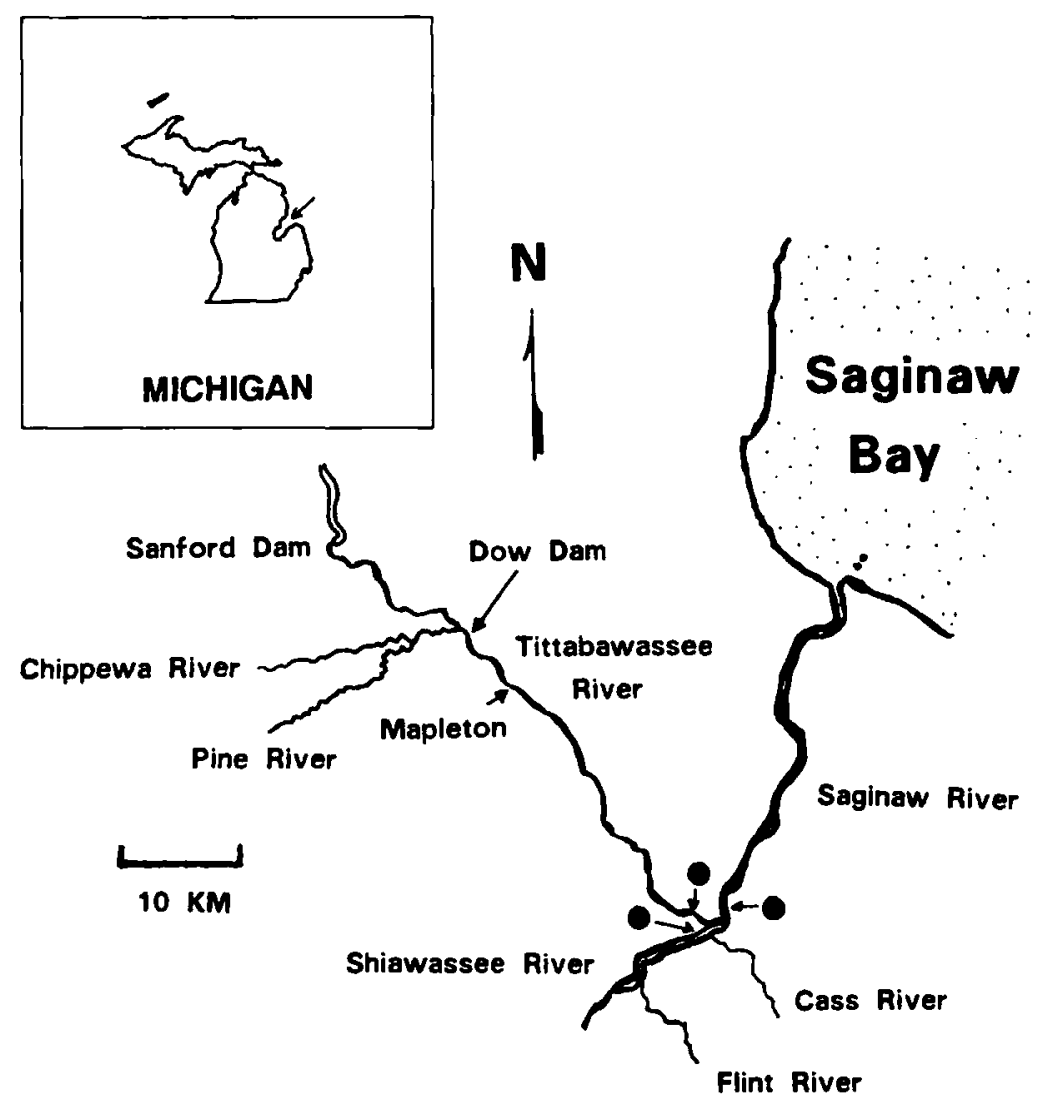

Ficiure 1.-Map showing Saginaw River tributaries to Saginaw Bay. Also shown are Sanford and Dow dams and Mapeleton, known walleye spawning sites. Sampling stations for larval walleyes are shown as solid circles. Insert map shows Michigan; arrow points to Saginaw Bay.

spawning success of adult walleyes in the Saginaw River tributary system, and (2) to determine the presence, distribution, and abundance of naturally produced walleyes in Saginaw River tributaries and Saginaw Bay.

\section{Study Area}

Sampling for larval walleyes was done on the Saginaw River at its confluence with the Tittabawassee River and the Shiawassee River (Figure 1). The Tittabawassee River drains $6,475 \mathrm{~km}^{2}$. In its upper reaches, the river has four hydropower dams; Sanford Dam, some $110 \mathrm{~km}$ from Saginaw Bay, prevents fish passage farther upstream. The first big spawning migrations in the early 1980s are believed to have originated from fish stocked in these four reservoirs (Mrozinski et al. 1991). The Tittabawassee River has a low gradient with many long sandy stretches that run through forest and farmland. It is about $1.5 \mathrm{~m}$ deep in the study area. Scattered areas of rocky substrate occur throughout the river, especially below Sanford Dam. The Chippewa and Pine rivers, tributaries of the Tittabawassee River, have suitable spawning substrates and reported walleye runs. Below the Dow Chemical Co. complex in Midland is Dow Dam, a low-head dam that formerly allowed fish passage only during high water; in 1988 it was modified to allow passage at other times as well. Dow Dam is $22 \mathrm{~km}$ downstream from Sanford Dam and $88 \mathrm{~km}$ from Saginaw Bay.

The Shiawassee River joins the Tittabawassee River to form the Saginaw River near Saginaw, Michigan. The Shiawassee River is also a lowgradient, sandy-bottom river. It runs through the Shiawassee National Refuge and is $1.5 \mathrm{~m}$ deep in the study section. It is joined just before its confluence with the Saginaw River by the Cass and Flint rivers. The 44-km-long Saginaw River winds through the two large cities of Saginaw and Bay City. It has heavy industrialized development along its banks, and most of the channel is dredged for 
navigation. The river is reinforced with riprap in large sections, receives treated industrial and domestic wastes, and has several toxic-waste dumps along its banks: consequently, the International Joint Commission has designated it an Area of Concern (Hartig 1988). During April-May 19871988, discharge of the four rivers composing the Saginaw River varied between 60 and $446 \mathrm{~m}^{3} / \mathrm{s}$ (USGS 1988, 1989).

\section{Methods}

Collection of larval fish. - To determine if natural reproduction of walleyes was occurring, duplicate. 10-min samples of larval fish were collected with a 0.5 -m-diameter, number $2(363-\mu \mathrm{m}$ mesh) nylon plankton net during 1987 and 1988 . Two modes of collection were used at each of three Saginaw River stations: one net was pushed in front of the boat at the surface and one net was towed behind the boat at a depth of $3 \mathrm{~m}$. Sampling generally was conducted for 5 min upstream and 5 min downstream. Because of their shallowness, only surface push-net samples (duplicated) were collected at one station each on the Tittabawassee and Shiawassee rivers. This sampling scheme resulted in 16 samples per trip.

Saginaw River stations were established along a bank-to-bank transect to gain information about the distribution of larval walleyes and to calculate the number of walleyes passing through a crosssection of the river over $24 \mathrm{~h}$. The transect, approximately $160 \mathrm{~m}$ long where the river has a maximum depth of $4 \mathrm{~m}$. was divided into three equal sections-west, channel, and east. To calculate the total number of walleye larvae passing by the transect during the period walleye larvae occurred in samples, the mean density of walleye larvae in 6-24 (usually 12) samples was multiplied by the total discharge of the river during 5-8-d periods. the sampling date serving as the midpoint of the interval. Discharge was calculated by summing discharge records for the four rivers that compose the Saginaw River (USGS 1988, 1989).

Sampling in 1987 was conducted about once a week from mid-April to mid-May. More-intensive sampling over a shorter time was done in 1988 , based on data from 1987. Each tow against the current was made at a speed of about $1.8 \mathrm{~m} / \mathrm{s}$ as indicated by measured distances along the river. Each net was equipped with a flowmeter to determine the volume of water sampled. Samples were preserved with $90 \%$ ethanol. All fish larvae were removed from samples, identified (Auer 1982), and measured to the nearest $0.1 \mathrm{~mm}$ total length.
Densities were calculated with computer programs that converted flowmeter readings to water volumes.

Calculation of larval flux. - The number of walleye larvae passing through the Saginaw River section was calculated from discharge and walleye density data. The river was traversed on 21 April 1987 and depth was recorded every $5 \mathrm{~s}$ or about every $7 \mathrm{~m}$. These data were used to calculate the cross-sectional area of the river. River width (159 m) was obtained from a USGS topographical map and was divided into three equal sections of $53 \mathrm{~m}$ each. Current velocity was measured with a Gurley current meter at 0.2 and 0.6 river depth at the midpoints of the east, channel, and west sections. (At other times and stations, current measurements were obtained at midchannel $1 \mathrm{~m}$ below the surface.) Each section was then divided in upper and lower halves and the cross-sectional area of each half was multiplied first by the mean velocity then by the mean density of walleye larvae $(N=$ 2 ) in that stratum. Larval fish collections on 21 April were performed during the day and the night to provide required data. The $24-\mathrm{h}$ period was divided by the sunset and sunrise times, and the calculations were weighted by the proportion of time in the night and day periods. Larval fluxes in the six subsections were summed to calculate the number of walleye larvae passing this point in the river in $24 \mathrm{~h}$.

\section{Results}

On 28 March 1987, walleyes were observed spawning in the Tittabawassee River at Mapleton, $8 \mathrm{~km}$ downstream from Dow Dam (Figure 1); water temperature was $7.7^{\circ} \mathrm{C}$ (L. Mrozinski, Michigan Department Natural Resources, personal communication). Walleyes appeared to be most numerous on 3 April, and spawning activity continued until 9-10 April. In 1988, ripe and spent females were observed on 12-13 April when water temperatures were $10-11.7^{\circ} \mathrm{C}$ at Dow Dam.

Sampling for larval walleyes was conducted nine times in 1987. No larval fish were collected from 20 March to 9 April, and only a few yellow perch larvae were collected on 16 April. Walleye larvae were first collected on 21 April (Figure 2) when water temperatures had increased sharply to almost $20^{\circ} \mathrm{C}$ (Figure 3; Table 1). Densities of larvae were two- to threefold higher at night than during the day in the Tittabawassee and Saginaw rivers. Daytime densities in the Saginaw River were 0 $103 / 1,000 \mathrm{~m}^{3}$, whereas at night they were $6-357 /$ $1,000 \mathrm{~m}^{3}$, which is a strong indication of net avoid- 
ance by larval walleyes during the day despite high turbidity (Secchi disk transparencies were 0.2-1.0 $\mathrm{m}$ : Table 1). Newly hatched walleyes are photopositive (Bulkowski and Meade 1983). However, during both day and night, more walleye larvae were collected near the bottom than near the surface in the Saginaw River (data not shown). More larvae were collected on the east side of the Saginaw River than in the channel or on the west side (Figure 2). Highest occurrence of larval walleyes seemed to coincide with increased water clarity, rising water temperatures, stabilized and lowered discharge (Table 1; Figure 3), and a noticeable increase in the abundance of drift organisms such as zooplankton and benthos (observed while removing larval walleyes from samples). In 1987 water temperatures declined in early April but rose continually thereafter to a peak around $19^{\circ} \mathrm{C}$ on 20 April (Figure 3). The greatest abundance of walleye larvae occurred on 21 April, right at the peak of rising water temperature; subsequently, larvae occurred with low frequency until 9 May. In 1988, water temperatures increased to midApril, then declined and remained stable through the end of the month. Temperatures then increased gradually through May. Walleye larvae occurred sporadically during the period of rising temperatures in late April to early May, then reached peak densities on 6 May when temperatures were around $16^{\circ} \mathrm{C}$.

Walleye larvae were of generally similar sizes on the three dates when they were collected in 1987. Most were collected during the intensive sampling on 21 April 1987 (Figure 4), and there did not appear to be any size differences between day and night samples nor between fish collected in the Saginaw and Shiawassee rivers. These larvae were $7-10.5 \mathrm{~mm}$ long with distribution modes at 8-9 mm. Fish from the Tittabawassee River were somewhat smaller, 7-7.5 $\mathrm{mm}$, and probably were newly hatched; walleyes are $5.8-8.7 \mathrm{~mm}$ when they hatch (Auer 1982).

On 21 April 1987, an estimated 536,900 walleye larvae passed the Saginaw River transect in $24 \mathrm{~h}$. A majority of larvae moved along the east side of the river, and more larvae passed in near-bottom than in near-surface waters (Table 2). An estimated 138,700 larvae passed the transect during the day and 398,200 drifted by at night. Over the period of walleye occurrence, from 19 April to 7 May 1987, approximately 3 million walleye larvae passed through the Saginaw River at the sampling site. During 17 April-7 May 1988, approximately 28 million walleye larvae passed through the study

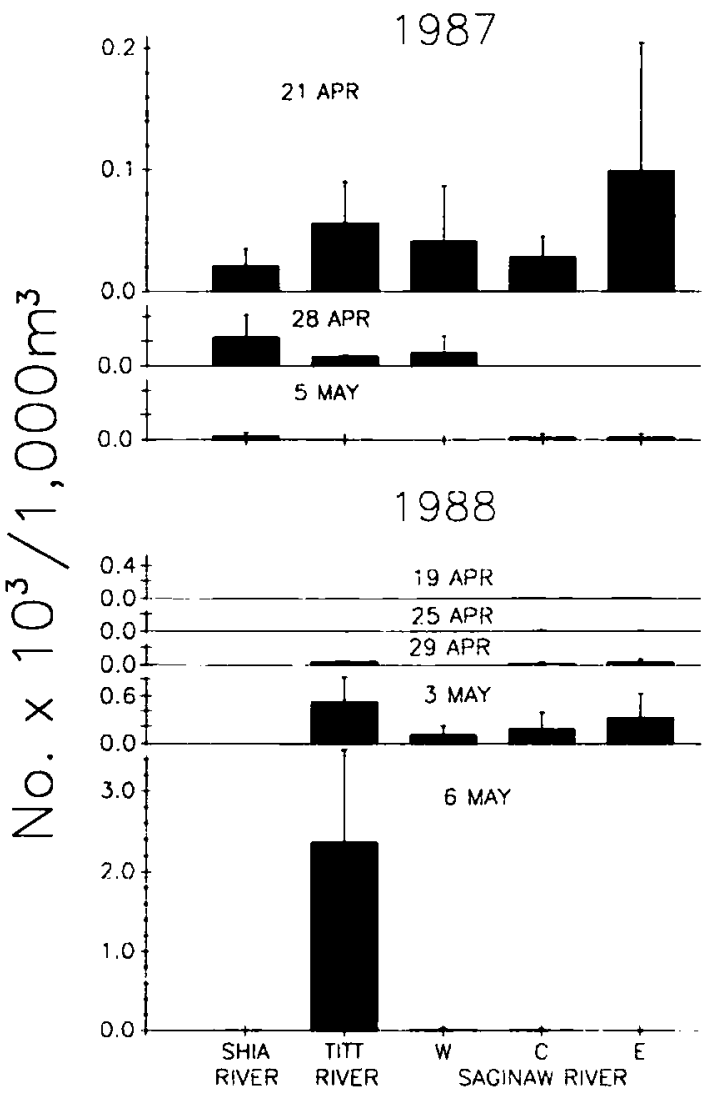

FigilRe 2.-Densities of larval walleyes collected from the Tittabawassee (Titt), Shiawassee (Shia), and Saginaw rivers during spring 1987 and 1988 . Standard deviations are shown as vertical lines; $\mathbf{E}=$ east side. $\mathrm{C}=$ channel. and $\mathbf{W}=$ west side of Saginaw River. Sample size was four at each station on the Saginaw River and two at each station on the other rivers. On 21 April. because of the 24-h sampling, sample size was doubled. Note that scales differ between 1987 and 1988.)

area. These are low-end estimates based on a conservative estimate of discharge (there are no gauging stations on the Saginaw River) and day densities, which (as shown) are substantially lower than night densities.

In 1988 (all daytime sampling), only a few larvae were collected on the first sampling date, 19 April, all in the Saginaw River (Figure 2). On 25 April, a few walleye larvae were collected in one sample from the Tittabawassee River and in two samples from the Saginaw River. Abundance increased on 29 April, when 9 of 21 samples contained small numbers of larvae, including both samples from the Tittabawassee River. Larval walleye were most widespread on 3 May, occurring at all stations (7$845 / 1,000 \mathrm{~m}^{3}$ ) except those in the Shiawassee Riv- 


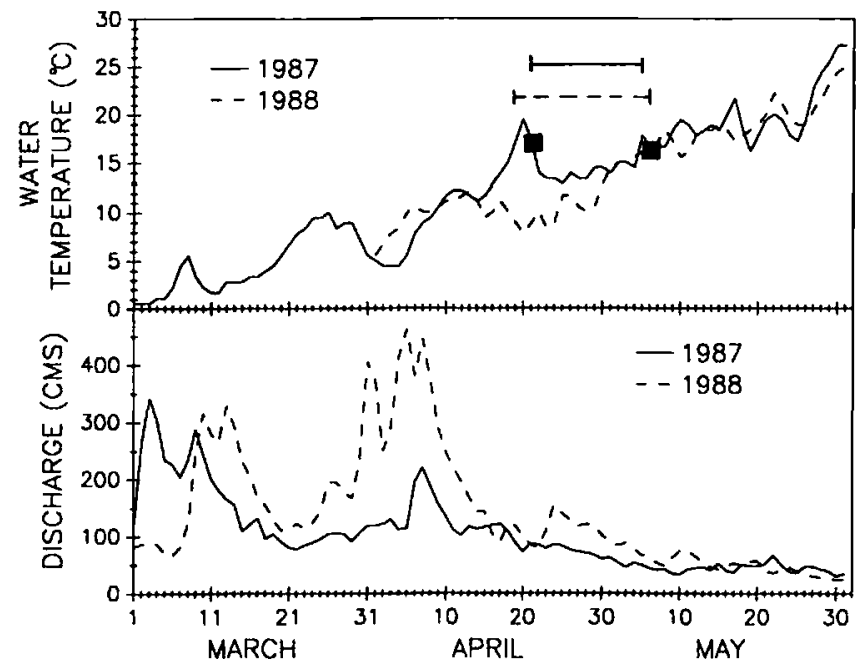

FiG: RE 3. - Daily temperatures from the Tittabawassee River below Dow Dam. 1 March-30 May 1987 and 1988 , and discharge $(\mathrm{cms}=\mathrm{cm} / \mathrm{s})$ from USGS gauging stations (USGS 1988, 1989). Discharges are sums of the four rivers (Shiawassee. Tittabawassee. Flint. and Cass) that merge to form the Saginaw River. Horizontal lines above the water temperature graph represent the inclusive dates of occurrence of walleye larvae; black boxes designate dates when maximum densities were observed.

er. Highest densities were recorded in the Tittabawassee River. Water temperatures on 3 May were $14.5-15.6^{\circ} \mathrm{C}$. On 6 May in the Tittabawassec River. the highest densities of any samples were recorded $-1.206-3,522 / 1,000 \mathrm{~m}^{3}$. These densities were almost 10 times the highest density (357/ $1,000 \mathrm{~m}^{3}$ ) recorded in 1987 . The discharge in the Tittabawassee River on 6 May 1988 was $36.5 \mathrm{~m}^{3 /} \mathrm{s}$. so with a mean density of 2,364 walleye larvae/ $1.000 \mathrm{~m}^{3}$, over 7 million larvae passed through this river system in $24 \mathrm{~h}$. It is clear that the Tittabawassee River was the major source of walleye larvae to the Saginaw River in 1988. Concurrent samples from the Saginaw River collected on 6 May showed considerably lower densities than those recorded in the Tittabawassee River (Figure

TABLE 1. - Physical characteristics of the Tittabawassee, Shiawassee, and Saginaw rivers during larval fish sampling in 1987 and $1988 . T=$ temperature, $S=$ Secchi disk readings, and $V=$ velocity: $E=$ cast side, $C=$ channel, and $W=$ west side of the Saginaw River.

\begin{tabular}{|c|c|c|c|c|c|c|c|c|c|c|c|}
\hline \multirow[b]{3}{*}{ Date } & \multicolumn{3}{|c|}{ Tittabawassee River } & \multicolumn{3}{|c|}{ Shiawassee River } & \multicolumn{5}{|c|}{ Saginaw River } \\
\hline & \multirow{2}{*}{$\begin{array}{c}\mathrm{T} \\
\left({ }^{\circ} \mathrm{C}\right)\end{array}$} & \multirow{2}{*}{$\underset{(m)}{S}$} & \multirow{2}{*}{$\begin{array}{c}V \\
(\mathrm{~cm} / \mathrm{s})\end{array}$} & \multirow{2}{*}{$\begin{array}{c}\mathrm{T} \\
\left({ }^{\circ} \mathrm{C}\right)\end{array}$} & \multirow{2}{*}{$\underset{(m)}{S}$} & \multirow{2}{*}{$\begin{array}{c}V \\
(\mathrm{~cm} / \mathrm{s})\end{array}$} & \multirow{2}{*}{$\begin{array}{c}\mathrm{T} \\
\left.{ }^{\circ} \mathrm{C}\right)\end{array}$} & \multirow{2}{*}{$\underset{(\mathrm{m})}{S}$} & \multicolumn{3}{|c|}{ Velocity $(\mathrm{cm} / \mathrm{s})$} \\
\hline & & & & & & & & & E & C & $\mathbf{w}$ \\
\hline \multicolumn{12}{|l|}{1987} \\
\hline 20 Mar & & & & & & & 4.3 & 0.8 & 41.0 & 47.0 & 53.0 \\
\hline 3 Apr & 4.8 & & & 4.8 & & & 4.4 & & & & \\
\hline $9 \mathrm{Apr}$ & 10.0 & 1.1 & & 9.5 & 0.4 & 54.2 & 9.4 & 0.4 & 56.0 & & \\
\hline $16 \mathrm{Apr}$ & 12.4 & 1.2 & & 12.9 & 0.4 & & 12.6 & 0.4 & & & \\
\hline $21 \mathrm{Apr}$ & 19.9 & 1.0 & & 19.8 & 0.2 & & 19.5 & 0.4 & 27.8 & 26.7 & 11.4 \\
\hline $28 \mathrm{Apr}$ & 13.9 & 1.0 & 25.6 & 14.1 & 0.2 & & 13.9 & 0.8 & 17.9 & 24.5 & 19.0 \\
\hline 5 May & 15.8 & 1.0 & 23.4 & 14.1 & 0.3 & 8.6 & 14.4 & 0.5 & 8.1 & 10.3 & 11.4 \\
\hline $18 \mathrm{May}$ & 20.5 & 0.6 & & 19.6 & 0.5 & & 19.0 & 0.4 & & & \\
\hline \multicolumn{12}{|l|}{1988} \\
\hline $19 \mathrm{Apr}$ & 9.4 & 0.7 & & 9.0 & 0.3 & & 8.6 & 0.3 & & & \\
\hline $25 \mathrm{Apr}$ & 10.4 & 0.5 & & 11.4 & 0.2 & & 11.1 & 0.2 & & & \\
\hline $29 \mathrm{Apr}$ & 9.9 & 1.1 & & 9.5 & 0.5 & & 9.1 & 0.6 & 30.0 & 23.4 & 19.6 \\
\hline 3 May & 14.5 & 1.0 & & 15.6 & 0.1 & & 14.5 & 0.3 & & & \\
\hline $6 \mathrm{May}$ & 15.5 & 0.9 & 9.2 & 15.8 & 0.3 & 20.7 & $16.7^{\mathrm{a}}$ & $0.2^{a}$ & 21.8 & 18.5 & 20.7 \\
\hline 12 May & 17.9 & 0.8 & 23.4 & 18.6 & 0.2 & & 17.2 & 0.3 & 23.9 & 28.3 & 23.4 \\
\hline
\end{tabular}

At the mouth of the Saginaw River on 6 May, temperature was $15.2^{\circ} \mathrm{C}$ and Secchi depth was $0.2 \mathrm{~m}$. 


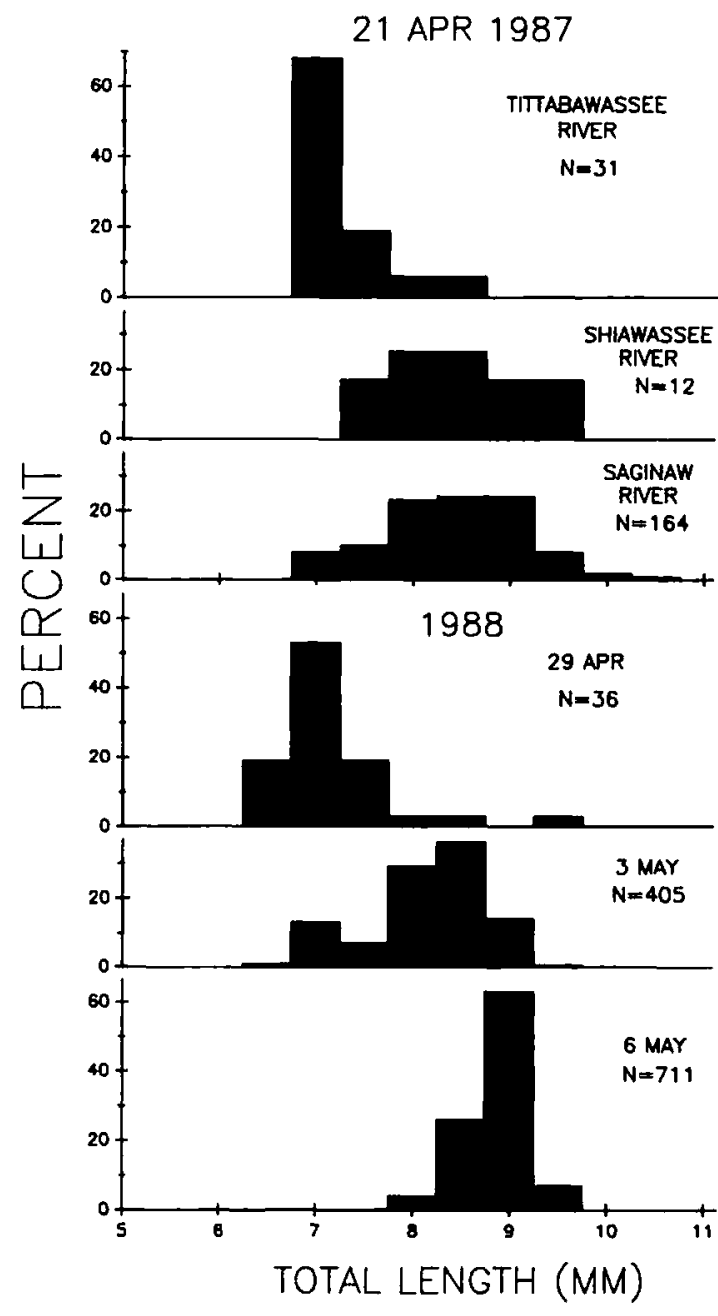

FiguRE 4.- Length-frequency distributions of larval walleyes by river on 21 April 1987 and on three dates in 1988. Data for all three rivers were pooled in 1988 because there was little difference among rivers.

2). Presumably, the trend of high numbers in the Tittabawassee River and low densities in the Saginaw River was due to dilution from the Shiawassee River. which seldom contained many walleye larvae. However, in 1987 more walleye larvae were found in the Saginaw River than in the Tittabawassee River. No walleyes were collected on 12 May, the last sampling date in 1988.

Length-frequency data for larval walleyes showed a pattern of increasing lengths with progressive sampling dates in 1988 (Figure 4). On 19 April, two $6-\mathrm{mm}$ larval walleyes were collected in the Saginaw River. On 25 April, four larvae $7-7.5 \mathrm{~mm}$ were captured; on 29 April, the mode was still at $7 \mathrm{~mm}$ but some larvae were $9.5 \mathrm{~mm}$ long. Larvae
TABLE 2.-Numbers of walleye larvae (in thousands) passing by the Saginaw River study site in 24 h, 21 April 1987. The cross-sectional area of the river was divided into six segments. and mean densities of walleye larvac $(N=2)$ in each segment were used with velocity data to calculate the total number.

\begin{tabular}{lccc}
\hline & \multicolumn{3}{c}{ Location } \\
\cline { 2 - 4 } \multicolumn{1}{c}{ Depth strata } & East & Channel & West \\
\hline \multirow{4}{*}{ Daytime } & & \\
Bottom & 8.1 & 8.5 & 1.7 \\
Combined & 75.8 & 28.1 & 16.5 \\
& 83.9 & 36.6 & 18.2 \\
Surface & Nighttime & \\
Bottom & 66.9 & 39.1 & 4.9 \\
Combined & 200.2 & 44.2 & 42.9 \\
\hline
\end{tabular}

were most widespread on 3 May, when modal length had increased to $8.5 \mathrm{~mm}$. Tittabawassee River walleye larvae were smaller $(6.5-8.5 \mathrm{~mm})$ than those captured in the Saginaw River (7-10 $\mathrm{mm}$ ), but the greater effort expended in collections on the Saginaw River could account for the larger walleye larvae. By 6 May, walleyes with a mode at $9 \mathrm{~mm}$ occurred in the Saginaw and Tittabawassee rivers.

To determine if walleye larvae were reaching Saginaw Bay in 1988, 1 sampled at the mouth of the Saginaw River on 7 May, 1-3 d after the occurrence of maximum densities. Three walleye larvae $(8.5-9.5 \mathrm{~mm})$ were collected in four $10-\mathrm{min}$ daytime tows for an average density of $35 / 1,000$ $\mathrm{m}^{3}$. Based on their large size, $I$ believe that these larvae originated from the Tittabawassee River. This finding suggests that at least some walleye larvae are reaching required nursery areas in Saginaw Bay.

\section{Discussion}

The distribution of walleye larvae has been studied extensively in lakes (Houde and Forney 1970; Spykerman 1974) but less in rivers (Priegel 1970). Walleyes are known to travel as far as $110 \mathrm{~km}$ from Saginaw Bay to spawn below Sanford Dam on the Tittabawassee River. Walleyes also spawn below Dow Dam and Mapleton, which are about $22 \mathrm{~km}$ closer to Saginaw Bay, the presumed nursery area. Elsewhere, walleyes travel up to $155 \mathrm{~km}$ to spawn in the Fox River system, Green Bay, Wisconsin (Priegel 1970); and Elrod et al. (1987) found that tributary embayments in midreservoir were principal nurseries for walleyes in Lake Sharpe, South Dakota. 
Walleye larvae were collected in the Saginaw River in latter April and early May; maximum densities occurred on 21 April 1987 and 6 May 1988. This timing agrees with data from other walleye studies of similar latitudes (Priegel 1970; Corbett and Powles 1986; Auer and Auer 1987). Maximum densities of fish larvae corresponded with increases of water temperatures to $16-19^{\circ} \mathrm{C}$. In 1987, water temperatures increased rapidly in spring, which apparently precipitated large-scale hatching and early maximum densities of walleye larvae. In 1988, water temperature increased gradually. which apparently delayed and prolonged hatching, because maximum densities occurred later in 1988 than 1987. In addition, density and abundance of walleye larvae were up to tenfold higher in 1988 than 1987. Johnson (1961) showed that best egg survival under natural conditions occurred in years of warm water and shortened incubation periods. In 1987 and 1988, walleye larvae occurred during stable river levels after the major spring runoff (Figure 3).

Based on the sampling data, I offer the following recommendations for future studies. There were many samples with no fish larvae at off-peak times. To increase catches and statistical robustness, sampling should be performed at night. Mesh size should be increased from $363 \mu \mathrm{m}$ (this study) to $571 \mu \mathrm{m}$ and net mouth diameter from 0.5 to 0.75 $\mathrm{m}$.

To reach Saginaw Bay, a larval walleye had to travel $110 \mathrm{~km}$ if it was spawned at Sanford Dam (Figure 1). Velocities measured during peak appearance of larval walleyes were $11-28 \mathrm{~cm} / \mathrm{s}$ in 1987 and $9-30 \mathrm{~cm} / \mathrm{s}$ in 1988 (Table 2). Therefore, a walleye larva would have required 4-14 d to reach Saginaw Bay from Sanford Dam if it drifted passively with the current and measured current velocities were typical of the whole river. Presumably, walleye larvae would reach Saginaw Bay sooner if hatched near Dow Dam, near Mapleton, or within the Saginaw River proper. Priegel (1970) found that walleye larvae must reach a suitable nursery area within $5 \mathrm{~d}$ or die. which generally concurs with laboratory studies (Koenst and Smith 1976; Barrows et al. 1988; Loadman et al. 1989; Colesante 1989). It appears that with the appropriate current, walleyes produced in the Saginaw River tributary system could reach Saginaw Bay within $5 \mathrm{~d}$. However, the longitudinal gradient of the Saginaw River is very shallow and there are many times when river flow near the mouth is reversed because of wind-generated waves from Saginaw Bay. Such physical events could impair survival if walleye larvae were confined to the river under low food conditions for too long (Forney 1966; Houde 1967, 1969; Houde and Forney 1970).

Data showing increasing lengths of larvae with time suggest that either walleyes were coming from widely separated spawning sites upstream or that some larvae were residing in the river rather than being passively carried to Saginaw Bay. Walleyes captured on 29 April 1988 had length modes around $7 \mathrm{~mm}$, those on 3 May were at $8.5 \mathrm{~mm}$. and those on 6 May were at $9 \mathrm{~mm}$. A common growth rate for larval walleyes is about $0.2-0.6$ $\mathrm{mm} / \mathrm{d}$ (Barrows et al. 1988), so larvae collected on 29 April, if they stayed in our study area, would be about the size collected on subsequent dates. These changes in length, however, were accompanied by large increases in abundance, which was contrary to expectations. Also, $9.55-\mathrm{mm}$ walleye larvae have swimming speeds of only $3-4 \mathrm{~cm} / \mathrm{s}$ (Houde 1969); thus they could not resist Saginaw River currents, which were generally greater than $15 \mathrm{~cm} / \mathrm{s}$. More likely, the larvae represented cohorts from more than one spawning location upstream.

Although walleyes are producing large numbers of larvae in the Saginaw River system, few of these larvae reach the Saginaw River mouth-only 35/ $1,000 \mathrm{~m}^{3}$ were found at the mouth in this study. Densities for walleyes are expected to be lower than for some other species, such as yellow perch. which attain larval fish densities up to $5,000 / 1,000$ $\mathrm{m}^{3}$ in Lake Michigan (Perrone et al. 1983). In similar efforts to evaluate walleye stocking programs, Forney (1975) found that wild fish made a small contribution in Oneida Lake, New York. The suspected low natural recruitment of walleyes in Saginaw Bay needs to be confirmed, but it suggests that rehabilitative measures now in place may not be adequate to ensure survival of naturally produced young. However, on 14-15 June 1988, Leo Mrozinski (Michigan Department of Natural Resources) collected seven 41 -mm-long, naturally produced walleyes from Saginaw Bay just east of the mouth of the Saginaw River. The presence of naturally reproducing walleyes is a positive sign of restoration for the Saginaw Bay ecosystem, but efforts at rehabilitation of the area still fall short if larval walleyes cannot survive to flourish in Saginaw Bay nurseries.

The Saginaw River and Bay was designated an International Joint Commission Area of Concern because of high nutrients and contaminated sediments, common carp Cyprinus carpio, and chan- 
nel catfish lctalurus punctatus. Baumann and Whittle (1988) noted that chlorinated dibenzofurans and dibenzo-p-dioxins were highest in fish from Saginaw Bay. Studies by the Michigan Department of Natural Resources showed degraded water quality, including low dissolved oxygen $(2-5 \mathrm{mg} / \mathrm{L})$ and high ammonia $(0.34 \mathrm{mg} / \mathrm{L})$ levels during JuneAugust 1988. However, Auer and Auer (1987) found that hatching success of walleye eggs incubated in the Fox River, which runs into Green Bay of Lake Michigan, was unaffected by degraded water quality. Lack of successful reproduction there was attributed to inadequate spawning substrate, toxic sediments, water temperature fluctuations, predation. and fungal infestation. In the Saginaw River, where large numbers of larval walleyes were collected. all of the above limiting factors can be eliminated except water temperature and predation.

Food availability or abundance may also be inadequate. Walleye eggs in hatcheries are incubated under ideal temperature regimes and probably hatch with more available yolk than do their wild counterparts in the Tittabawassee River. Hatchery fry are stocked into fertile ponds managed for large daphnids. Prey abundance in the Saginaw River may be low, and capture efficiency may be impeded by high turbidity levels. Larvae of striped bass Morone saxatilis, when fed natural prey assemblages consisting mostly of copepods, consumed $40 \%$ fewer prey in total suspended solids concentrations of 200 and $500 \mathrm{mg} / \mathrm{L}$ than in 0 or $75 \mathrm{mg} / \mathrm{L}$ : in contrast, feeding on Daphnia pulex was unaffected (Breitburg 1988). Concentrations of total suspended solids in the Saginaw River measured by the Michigan Department of Natural Resources ranged from 27 to $66 \mathrm{mg} / \mathrm{L}(N=14)$ during June-August 1988. Values were undoubtedly much higher during spring runoff when Secchi disk measurements during times of occurrence of walleye larvae averaged $0.4 \mathrm{~m}$.

Walleye reproduction and survival to at least the larval stage is occurring in the Saginaw River tributary system, and a large proportion of the progeny are clearly from fish stocked into Saginaw Bay. However. apparent reductions in densities of larval walleye as larvae drift down the Saginaw River indicate this source of walleye larvae is contributing little to the Saginaw Bay walleye population. The tributaries may not be the optimal spawning sites for walleyes; Schneider (1977) and Schneider and Leach (1977) argued that, historically, the walleye population was sustained by spawning on offshore reefs. The problem of poor recruitment of larval walleyes to Saginaw Bay could be related to contaminants, eutrophication (Koonce et al. 1977). excessive distance between spawning site and nursery area (Priegel 1970), food availability (Laurence 1974: Mathias and $\mathrm{Li}$ 1982), predation (Maloney and Johnson 1957), or reversal of water flow at the mouth of the Saginaw River. The success of the Michigan Department of Natural Resources Remedial Action Plan for this Area of Concern depends on restoring all functions in the ecosystem, including natural reproduction of walleyes, unsupplemented by stocking.

\section{Acknowledgments}

I thank the following people for their contributions to the success of this project. Leo Mrozinski and Jim Baker, Michigan Department of Natural Resources, provided advice. reviews, encouragement, and fish during the course of the study. I was assisted in the collection of larval fish by a cadre of enthusiastic and dedicated biologists. including Hong Zhang, Jim Wojcik, Bob Springborn, Morris Flexner, Michael Gallinat, Pamela Mansfield, and Mary Sweeney. Heang Tin. Philip Hin, Michael Gallinat. and Hong Zhang processed larval fish samples. Pamela Mansfield, Scott DeBoe, and Jim Barres provided computer programing and statistical assistance. Mel Turner of the Saginaw Marina, Saginaw, Michigan. graciously provided a slip for our use during spring sampling. Gary Miller, Dow Chemical Co., provided water temperature data. Carole Fletcher helped with budget matters, and Bev McClellan processed all the words. Joseph Leach, Nancy Auer. Philip Schneeberger. and Roger Knight are gratefully acknowledged for their incisive reviews. This publication is a result of work sponsored by the Michigan Sea Grant College Program, project R/GLF-30 NA86AA-D-SGO43, through the Office of Sea Grant, National Oceanic and Atmospheric Administration. U.S. Department of Commerce, and further funded by the state of Michigan. The U.S. government is authorized to produce and distribute reprints for governmental purposes notwithstanding any copyright notation appearing hereon. This is contribution 550 of the Center for Great Lakes and Aquatic Sciences.

\section{References}

Auer, N. A.. editor. 1982. Identification of larval fish of the Great Lakes basin with emphasis on the Lake Michigan drainage. Great Lakes Fishery Commission. Special Publication 82-3, Ann Arbor. Michigan. 
Auer, N. A., and M. T. Auer, 1987. Field evaluation of barriers to walleye egg and larva survival in the lower Fox River. Wisconsin. American Fisheries Society Symposium 2:93-101.

Baldwin, N. S., and R. W. Saalfeld. 1962. Commercial fish production in the Great Lakes. Great Lakes Fishery Commission Technical Report 3.

Barrows. F. T., W. A. Lellis, and J. G. Nickum. 1988. Intensive culture of larval walleyes with dry or formulated feed: note on swim bladder inflation. Progressive Fish-Culturist 50:160-166.

Baumann, P. C., and D. M. Whittle. 1988. The status of selected organics in the Laurentian Great Lakes: an overview of DDT, PCBs, dioxins, furans, and aromatic hydrocarbons. Aquatic Toxicology 11:241257.

Bierman, V. J., Jr., and D. M. Dolan. 1986a. Modeling of phytoplankton in Saginaw Bay. I. Calibration phase. Journal of Environmental Engineering 112: $400-414$.

Bicrman. V. J., Jr., and D. M. Dolan. 1986b. Modeling of phytoplankton in Saginaw Bay. II. Post-audit phase. Journal of Environmental Engineering 112: 415-429.

Breitburg, D. L. 1988. Effects of turbidity on prey consumption by striped bass larvae. Transactions of the American Fisheries Society 117:72-77.

Bulkowski, L., and J. W. Meade. 1983. Changes in phototaxis during early development of walleye. Transactions of the American Fisheries Society 112 : $445-447$.

Colesante. R. 1989. Improved survival of walleye fry during the first 30 days of intensive rearing on brine shrimp and zooplankton. Progressive Fish-Culturist 51:109-111.

Corbett. B. W., and P. M. Powles. 1986. Spawning and larva drift of sympatric walleyes and white suckers in an Ontario stream. Transactions of the American Fisheries Society 115:41-46.

Elrod, J. H., F. C. June, and L. G. Beckman. 1987. Biology of the walleye in Lake Sharpe. South Dakota, 1964-1975. U.S. Fish and Wildlife Service, Fish and Wildlife Technical Report 8:46-60.

Forney, J. L. 1966. Factors affecting first-year growth of walleyes in Oneida Lake, New York. New York Fish and Game Journal 13:146-167.

Forney, J. L. 1975. Contribution of stocked fry to walleye fry populations in New York lakes. Progressive Fish-Culturist 37:20-24.

Hartig. J. H. 1988. Remedial action plans: IAGLRs opportunity and responsibility. Joumal of Great Lakes Research 14:129-1 30.

Houde. E. D. 1967. Food of pelagic young of the walleye. Stizostedion vitreum vitreum, in Oneida Lake, New York. Transaction American Fisheries Society 96:17-24.

Houde. E. D. 1969. Sustained swimming ability of larvae of walleye (Stizostedion vitreum vitreum) and yellow perch (Perca flavescens). Journal of the Fisheries Research Board of Canada 26:1647-1659.

Houde. E. D., and J. L. Forney. 1970. Effects of water currents on distributions of walleye larvae in Oneida
Lake. New York. Journal of the Fisheries Research Board of Canada 27:445-456.

IJC (International Joint Commission). 1980. Report on Great Lakes water quality. Great Lakes Water Quality Board, Windsor, Ontario.

Johnson, F. H. 1961. Walleye egg survival during incubation on several types of bottom in Lake Winnibigoshish, Minnesota, and connecting waters. Transactions of the American Fisheries Society 90: 312-322.

Koenst, W. M., and L. L. Smith, Jr. 1976. Thermal requirements of the early life history stages of walleye. Stizostedion vitreum. and sauger. Stizostedion canadense. Journal of the Fisheries Research Board of Canada 33:1 130-1138.

Koonce, J. F., T. B. Bagenal, R. F. Carline, K. Hokanson. and M. Nagiec. 1977. Factors influencing yearclass strength of percids: a summary and a model of temperature effects. Journal of the Fisheries Research Board of Canada 34:1900-1909.

Laurence, G. C. 1974. Growth and survival of haddock (Melanogrammus aeglefinus) larvae in relation to planktonic prey concentration. Journal of the Fisheries Research Board of Canada 31:1415-1419.

Leach. J. H., M. G. Johnson, J. R. M. Kelso, J. Hartman, W. Numann, and B. Entz. 1977. Responses of percid fishes and their habitats to eutrophication. Journal of the Fisheries Research Board of Canada 34:1964-1971.

Loadman. N. L., J. A. Mathias, and G. E. E. Moodie. 1989. Method for the intensive culture of walleye. Progressive Fish-Culturist 51:1-9.

Maloney, J. E., and F. H. Johnson. 1957. Life histories and inter-relationships of walleye and yellow perch, especially during their first summer, in two Minnesota lakes. Transactions of the American Fisheries Society $85: 191-202$.

Mathias. J., and S. Li. 1982. Feeding habits of walleye larvae and juveniles: comparative laboratory and field studies. Transactions of the American Fisheries Society 111:722-735.

Mrozinski, L. E., J. C. Schneider, R. C. Haas, and R. E. Shepherd. 1991. Rehabilitation of walleye in Saginaw Bay, Lake Huron. Pages 63-84 in P. J. Colby, C. A. Lewis, and R. L. Eshenroder, editors. Status of walleye in the Great Lakes: case studies prepared for the 1989 workshop. Great Lakes Fishery Commission, Special Publication 91-1. Ann Arbor. Michigan.

Perrone, M., Jr., P. Schneeberger, and D. Jude. 1983. Distribution of larval yellow perch (Perca flavescens) in the nearshore waters of southeastern Lake Michigan. Journal of Great Lakes Research 9:517522.

Priegel, G. R. 1970. Reproduction and early life history of the walleye in the Lake Winnebago region. Wisconsin Department of Natural Resources Technical Bulletin 45.

Schneider, J. C. 1977. History of the walleye fisheries of Saginaw Bay, Lake Huron. Michigan Department of Natural Resources, Fisheries Research Report 1850. Ann Arbor. 
Schneider, J. C., and J. H. Leach. 1977. Walleye (Stizostedion vitreum vitreum) fluctuations in the Great Lakes and possible causes, 1800-1975. Journal of the Fisheries Research Board of Canada 34:18781889.

Spykerman, V. L. 1974. Food habits, growth and distribution of larval walleye, Stizostedion vitreum vitreum (Mitchill), in Clear Lake, lowa. Proceedings of the lowa Academy of Science 81:143-149.
USGS (U.S. Geological Survey). 1988. Water resources data, Michigan water year 1987. U.S. Geological Survey, Water-Data Report MI-87-I, Lansing, Michigan.

USGS (U.S. Geological Survey). 1989. Water resources data, Michigan water year 1988. U.S. Geological Survey, Water-Data Report MI-88-1, Lansing, Michigan. 